\title{
Chemistry and Bioactivity of Haplopappus remyanus ("bailahuen"), a Chilean Medicinal Plant
}

\author{
Francesca Faini, ${ }^{*, a}$ René Torres, ${ }^{b}$ Jesús M. Rodilla, ${ }^{c}$ Cecilia Labbé, ${ }^{a}$ Carla Delporte ${ }^{d}$ and Fabián Jaña ${ }^{a}$ \\ ${ }^{a}$ Departamento de Química, Facultad de Ciencias and ${ }^{d}$ Departamento de Química Farmacológica y Toxicológica, \\ Facultad de Ciencias Químicas y Farmacéuticas, Universidad de Chile, Santiago, Chile \\ ${ }^{b}$ Departamento de Ciencias del Ambiente, Facultad de Química y Biología, \\ Universidad de Santiago, Santiago, Chile \\ 'Departamento de Química, Universidade da Beira Interior, 6201-001 Covilha, Portugal
}

A cromatografia do extrato resinoso das partes aéreas de Haplopappus remyanus conduziu ao isolamento do ácido 18-acetoxilabda-7,13E-dien-15-óico, assim como dos derivados monoterpênicos 9-hidróxi- $\alpha$-terpineol, 9-benzoilóxi- $\alpha$-terpineol, 7-hidróxi-9-benzoilóxi- $\alpha$ terpineol e 9-benzoilóxi-(1-formil)- $\alpha$-terpineol. As estruturas para os novos compostos foram propostas com base em evidências espectroscópicas. A presença de quercetina e de outros cinco flavonóides conhecidos e identificados neste estudo pode ser responsável pela alta atividade antioxidante descrita e pelo moderado efeito tópico anti-inflamatório sobre edema de orelha induzido. Uma avaliação MTT com células tumorais CCRF-CEM mostrou 50\% da atividade citotóxica exibida pela doxorubicina nas mesmas condições. Diferenças quantitativas na composição química foram detectadas em comparação com estudos prévios com a mesma espécie, as quais podem ser atribuídas a fatores ambientais.

Chromatography on the resinous extract of aerial parts of Haplopappus remyanus led to the isolation of 18-acetoxy-labda-7,13E-dien-15-oic acid along with the monoterpene derivatives 9 -hydroxy- $\alpha$-terpineol, 9-benzoyloxy- $\alpha$-terpineol,7-hydroxy-9-benzoyloxy- $\alpha$-terpineol and 9-benzoyloxy-(1-formyl)- $\alpha$-terpineol. Structures for the new compounds are proposed on spectroscopic evidence. The presence of quercetin and five other known flavonoids identified in this study could account for the reported high antioxidant activity and the moderate topic antiinflammatory effect on induced ear oedema. MTT assay with CCRF-CEM tumor cells showed $50 \%$ of the cytotoxic activity displayed by doxorubicin under the same conditions. Quantitative differences in chemical composition were detected in comparison with previous studies of the species that could be attributed to environmental factors.

Keywords: Haplopappus remyanus, anti-inflammatory activity, cytotoxic activity, 9-hydroxy$\alpha$-terpineol esters, flavonoids

\section{Introduction}

Haplopappus remyanus Wedd (Asteraceae) is a resinous aromatic shrub endemic to Central Chile. ${ }^{1}$ This species is one of seventeen native Haplopappus spp., widely commercialized as "bailahuen" in herbal teas. They have the same vernacular name and identical uses in traditional medicine as $H$. baylahuen, which has digestive, antispasmodic and antiseptic properties. ${ }^{2}$ In relation to their antiseptic uses, a comparative antimicrobial study

\footnotetext{
*e-mail: ffaini@uchile.cl
}

of resinous exudate from nine Chilean Haplopappus spp., including some in the "bailahuen" cluster, reported very similar antibiotic activity for all extracts, although their chemical composition showed striking differences ${ }^{3}$ and no chemical correlations could be established among the medicinal species.

In order to find scientific support for the antispasmodic reputation of "bailahuen" species, we first compared the radical scavenging capacity (DPPH) of different types of extracts ${ }^{4}$ obtained from leaves of $H$. baylahuen, H. taeda, H. multifolius and $H$. remyanus. The results of bioassays showed that $H$. baylahuen extracts, rich 
in terpenoids, were the least active and that the higher activity of extracts from the other species could be attributed to the presence of coumarins (H. multifolius) and flavonoids ( $H$. taeda and H. remyanus), as seen by TLC. These preliminary results were corroborated with further chemical studies on H. taeda and H. multifolius, ${ }^{5,6}$ where the radical scavenging activity of different types of aromatic compounds isolated was tested.

On the other hand, in a chemical analysis of an extract obtained from aerial parts of $H$. remyanus, Zdero et al. ${ }^{7}$ reported the isolation of three dihydroflavones, two labdanoic acids and six monoterpene esters. According to their results the extract consisted mainly in the flavanones pinostrobin and pinobanksin 3-acetate, usually found in propolis. Although these flavanones have pharmacological effects related with antioxidant activity, they cannot account for the observed high radical scavenging activity of $H$. remyanus extract in the DPPH bioassay, as they lack the required catechol moiety in ring B. ${ }^{8}$ Besides, these results were not consistent with our TLC analysis of the resinous extract of the species, where the presence of several flavonoid derivatives could be clearly detected. ${ }^{4}$ In order to corroborate these preliminary results and in continuation with our survey on the bioactivity of the "bailahuen" cluster, we now report the results of anti-inflammatory and cytotoxic bioassays performed with a dichloromethane extract obtained from leaves of $H$. remyanus. The presence of four characteristic monoterpenes and seven flavonoids detected in the resinous exudate is discussed in terms of their effect on the medicinal properties attributed to this species.

\section{Experimental}

\section{Plant material and extraction}

Aerial parts were collected at Limarí province (IV Región) in September 2005 and identified as H. remyanus by Dr. Federico Luebert. A voucher specimen was deposited in the herbarium of Facultad de Agronomía (Universidad de Chile). The resinous exudate of fresh leaves was extracted by immersion ( $30 \mathrm{~s})$ in dicloromethane at room temperature and the filtered solution was then concentrated under reduced pressure to give the resin extract $(60 \mathrm{~g}, 13.4 \%$ dry wt).

\section{Chemical analysis}

Part of the extract ( $4.6 \mathrm{~g}$ ) was partitioned by column chromatography (CC) with Sephadex LH20 and methanol into two fractions, $\mathrm{T}(3.09 \mathrm{~g})$ and $\mathrm{F}(1.48 \mathrm{~g})$ (mainly terpenes and flavonoids respectively). Fractions were submitted to repeated flash $\mathrm{CC}$ in silicagel, using different solvent systems $\left(\mathrm{CH}_{2} \mathrm{Cl}_{2} / \mathrm{MeOH}, \mathrm{CH}_{2} \mathrm{Cl}_{2} /\right.$ EtOAc and Hexane/EtOAc) and elution with mixtures of increasing polarity. Further purification of compounds was achieved by rotatory (chromatotron) or preparative chromatography. Known flavonoids and terpenoids were identified by their ${ }^{1} \mathrm{H}$ NMR spectra in comparison with reported data and by TLC co-chromatography with previously isolated standards, when available. Structures for new compounds are proposed on the basis of their spectroscopic properties in comparison with closely related terpenoids isolated from H. taeda and H. remyanus. ${ }^{5,7}$ NMR spectra were obtained at $400 \mathrm{MHz}$ in $\mathrm{CDCl}_{3}$ (Bruker instrument) and $\mathrm{FAB}$ mass spectra of $\mathbf{4}$ was recorded with a FISONS VG AUTOSPEC mass spectrometer.

Fraction $\mathrm{T}$ afforded the known ${ }^{7}$ labdanoic acid $\mathbf{1}(5 \mathrm{mg})$ and its acetate derivative $\mathbf{2}(100 \mathrm{mg}$ ) along with 9-hydroxy$\alpha$-terpineol 3 and the related esters 4-6. Fraction F afforded quercetin $7(100 \mathrm{mg})$ and a complex mixture that could only be partially resolved by repeated preparative TLC to give semipurified samples (5-30 mg) of 8-13 that were used to run their ${ }^{1} \mathrm{H}$ NMR spectra.

\section{8-Acetoxy-labda-7,13E-dien-15-oic acid (2)}

Colourless oil $(0.1 \mathrm{~g}),{ }^{1} \mathrm{H}$ NMR $\left(\mathrm{CDCl}_{3}, \delta_{\mathrm{H}}\right.$, TMS internal reference): 0.80 (s, 3H, Me-20), 0.91 (s, 3H, Me-19), 1.70( s, 3H, Me-17), 1.87 (m, 2H, H-6), 2.08 (s, $3 \mathrm{H}, \mathrm{MeCO}$ ), 2.10 (m, 1H, H-12), 2.19 (s, 3H, H-16), 2.37 (m, 1H, H-12'), 3.68 (d, J 10.9 Hz,1H, H-18), 3.79 (d, $J 10.9 \mathrm{~Hz}, 1 \mathrm{H}, \mathrm{H}-18^{\prime}$ ), 5.39 (brs, 1H, H-7), 5.71 (s, 1H, $\mathrm{H}-14), 10.5$ (brs, 1H, COOH).

\section{9-Hydroxy- $\alpha$-terpineol (3)}

Colourless oil $(0.02 \mathrm{~g}),{ }^{1} \mathrm{H}$ NMR in Table 1.

\section{9-Benzoyloxy-(1-formyl)- $\alpha$-terpineol (4)}

Colourless oil $(0.06 \mathrm{~g}),{ }^{1} \mathrm{H}$ NMR in Table $1 .{ }^{13} \mathrm{C}$ NMR $\left(\mathrm{CDCl}_{3}, \delta\right.$, TMS internal reference): 141.2 (s, C-1), 150.6 (d, C-2), 27.1 (t, C-3); 40.8 (d, C-4), 22.7 (t, C-5), 22.0 (t, C-6), 193.8 (d, C-7), 73.4 (s, C-8), 70.2 (t, C-9), 21.2 (q, C-10), 166.6 (s, C=O); 129.6 (d, C-1', C-2' and C-6'); 128.5 (d, C-3', C-5') and 133.3 (d, C-4'). MS: TOF HRMS m/z: $311.1262\left[\mathrm{M}^{+}+\mathrm{Na}\right]$ (calc. for $\mathrm{C}_{17} \mathrm{H}_{20} \mathrm{O}_{4} \mathrm{Na}, 311.12538$ ) (100), $149.0168\left[\mathrm{M}^{+}-\mathrm{C}_{7} \mathrm{H}_{5} \mathrm{O}_{2}-\mathrm{H}_{2} \mathrm{O}\right]$ (21).

9-Benzoyloxy- $\alpha$-terpineol (5)

Colourless oil $(0.08 \mathrm{~g}),{ }^{1} \mathrm{H}$ NMR in Table 1.

7-Hydroxy-9-benzoyloxy- $\alpha$-terpineol (6) Colourless oil (0.014 g), ${ }^{1} \mathrm{H}$ NMR in Table 1. 


\section{Cell culture}

Suspensions of CCRF-CEM tumor cells (acute lymphoblastic leukemia) were prepared in RPMI-1640 medium supplemented with $100 \mathrm{IU} \mathrm{mL}^{-1}$ of penicillin, $100 \mu \mathrm{g} \mathrm{mL} \mathrm{L}^{-1}$ of streptomycin and $10 \%$ newborn calf serum. Cells were dispensed into each well of 96-well flat-bottom plates, with triplicate assays for each group. The culture was incubated at $37{ }^{\circ} \mathrm{C}$ in a humidified atmosphere of $5 \%$ $\mathrm{CO}_{2}$ in air for 48 h. ${ }^{9}$ After incubation, cell viability was measured by MTT assay.

\section{MTT-microculture tetrazolium assay}

Cell growth in the presence or absence of experimental agents was determined using the MTT-microculture tetrazolium assay. ${ }^{10}$ Briefly, after $48 \mathrm{~h}$ culture, the cells were incubated with MTT (500 $\left.\mu \mathrm{g} \mathrm{mL}^{-1}\right)$, then, $4 \mathrm{~h}$ later, $100 \mu \mathrm{L}$ of $10 \% \mathrm{SDS}-5 \%$ isobutanol- $0.12 \% \mathrm{HCl}$ solution was added to each well of the 96-well plates to solubilize the MTTformazan product. The culture plates were incubated for another $12 \mathrm{~h}$. Absorbance at $570 \mathrm{~nm}$ (A570) was measured with an enzyme-linked-immunosorbent-assay (ELISA) plate reader. Analysis of the relationship between measured A570 and number of viable CCRF-CEM cells indicated that cell densities at $2.5-80 \times 10^{4}$ cells per $\mathrm{mL}$ gave rise to a detectable and relatively linear range of absorbance values $(r=0.98)$. Citotoxicity was obtained by comparison of A570 with control wells without extract. Thus, $\mathrm{IG}_{50}$ were determined as the concentration of extract that reduces by $50 \%$ the cell growth of treated cells with respect to untreated controls. Doxorubicin was used as positive control $\left(\mathrm{IG}_{50}=0.0179 \mu \mathrm{g} \mathrm{mL}^{-1}\right.$, equivalent to $\left.0.033 \mu \mathrm{mol} \mathrm{L}-1\right) .{ }^{11}$

\section{Statistical analysis}

Data were obtained as the mean \pm SEM for the indicated number of experiments. All statistical analysis of data were performed by one-way ANOVA, followed by the test with $\mathrm{p}<0.01$ considered significant.

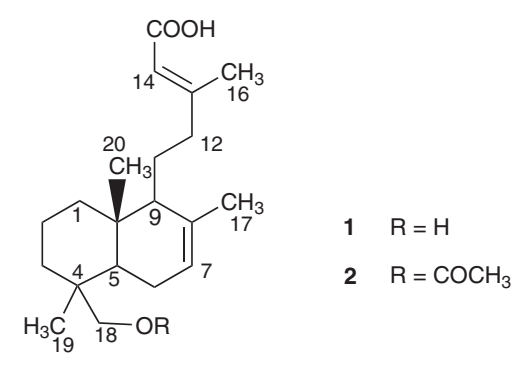

\section{Topical anti-inflammatory assay}

Experiments were conducted using mice (20-25 g) and the anti-inflammatory activity of the total extract ( $3 \mathrm{mg}$ ) was determined in vivo by inducing an epidermic inflammation on the ear of the animals with arachidonic acid (2 mg), as described by Lloret and Moreno. ${ }^{12}$ Nimesulide was used as reference ( $1 \mathrm{mg}$ per $20 \mu \mathrm{L}$ per ear) at a dose that produces maximum anti-inflammatory effect ${ }^{13}(48.8 \%)$. Topical anti-inflammatory activity of the extract was obtained by comparison of mean values of edemas in the group of treated animals with those found in the control group. Significant values were determined using Wilcoxon method for independent data.

\section{Results and Discussion}

Sephadex column chromatography (LH20, methanol) on the extract proved to be a useful means to separate oily terpenoids from flavonoids, as they eluted at different rates. The terpenoid mixture $(\mathrm{T})$ was complex and after repeated column chromatography afforded six compounds (1-6). Comparison of ${ }^{1} \mathrm{H}$ NMR spectra with data reported by Zdero et al. ${ }^{7}$ for terpenoids previously isolated from $H$. remyanus, led to the identification of $\mathbf{1}$ as 18 -hydroxylabda-7,13E-dien-15-oic acid. The ${ }^{1} \mathrm{H}$ NMR spectrum of 2 (see Experimental) was consistent with 18-acetoxy-labda7,13E-dien-15-oic acid as it had an acetate group $\left(\delta_{\mathrm{H}} 2.01\right)$ and the expected shift of the H-18 AB system $(\Delta \delta=0.5)$ on esterification. Other resonances remained identical to those found in the ${ }^{1} \mathrm{H}$ NMR spectrum of $1 .^{7}$

Joint analysis of ${ }^{1} \mathrm{H}-\mathrm{NMR}$ spectra of 3-6 (Table 1) showed that they were closely related monoterpenes. A comparison with reported $\mathrm{data}^{5,7}$ for monoterpenes isolated from $H$. taed $a$ and $H$. remyanus, easily identified $\mathbf{3}$ as 9-hydroxy$\alpha$-terpineol and suggested that 4-6 were benzoate esters of 3 with slight modifications in the main skeleton (Figure 1).

Compound 4 was isolated as a colourless oil (HRMS $\mathrm{C}_{17} \mathrm{H}_{20} \mathrm{O}_{4}$ ), and it reveals on TLC as a distinctive yellowgreen spot.

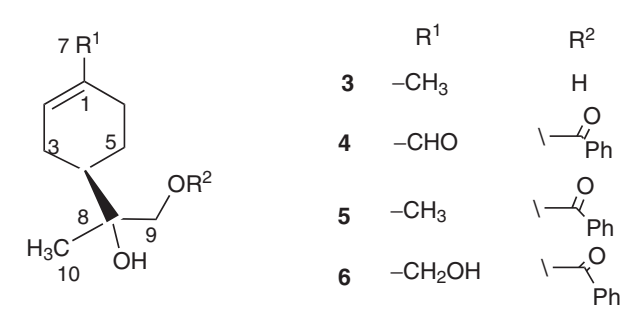

Figure 1. Structures of terpenoids isolated from H.remyanus. 
Analysis of ${ }^{1} \mathrm{H},{ }^{13} \mathrm{C}$ NMR spectra and DEPT experiments showed characteristic resonances for an aldehyde group $\left(\delta_{\mathrm{C}} 193.8 \mathrm{~d}\right.$, and $\left.\delta_{\mathrm{H}} 9.46 \mathrm{~s}\right)$, an ester carbonyl $\left(\delta_{\mathrm{C}} 166.6 \mathrm{~s}\right)$, a tri-substituted double bond $\left(\delta_{\mathrm{H}} 6.87,1 \mathrm{H}, \delta_{\mathrm{C}} 141.2 \mathrm{~s}\right.$ and $150.6 \mathrm{~d}$ ), a monosubstituted benzene ring, two carbons bearing oxygen $\left(\delta_{\mathrm{C}} 73.4 \mathrm{~s}\right.$ and $\left.70.2 \mathrm{t}, \delta_{\mathrm{H}} 4.37 \mathrm{brs}, 2 \mathrm{H}\right)$, a tertiary methyl group $\left(\delta_{\mathrm{C}} 21.2 \mathrm{q}, \delta_{\mathrm{H}} 1.31 \mathrm{~s}\right), \mathrm{a} \mathrm{CH}$ $\left(\delta_{\mathrm{C}} 40.8 \mathrm{~d}\right)$ and three methylene groups. Comparison with 3 (Table 1) and reported data for 9-dihydrocinnamoyloxyand 9-trans-p-coumaroyloxy- $\alpha$-terpineol $1^{5,7}$ allowed the assignment of all signals. Allocation of the aldehyde group to C-7 was evident from the downfield shift of H-2 $\left(\delta_{\mathrm{H}} 6.87\right)$, indicating a conjugated system. Esterification of the primary alcohol (C-9) followed from the downfield shift of the H-9 AB system that collapsed into a broad singlet $\left(\delta_{\mathrm{H}} 4.37,2 \mathrm{H}\right)$, as well as with the high field shift of the tertiary methyl group $\left(\delta_{\mathrm{H}} 1.31 \mathrm{~s}, 3 \mathrm{H} \mathrm{C}-10\right)$, next to the primary alcohol. On these basis compound $\mathbf{4}$ was identified as 9-benzoyloxy-(1-formyl)- $\alpha$-terpineol. TOF MS was in good agreement with this assignment as it showed two main peaks $(\mathrm{m} / \mathrm{z}, 311$ and 149$)$. The most prominent arises from $[\mathrm{M}+\mathrm{Na}]^{+}$. Loss of water from the tertiary alcohol and elimination of the aromatic ester ( $\phi \mathrm{COO}^{*}$ ) could account for the peak $m / z 149$, as expected for benzoate esters.

Compounds $\mathbf{5}$ and $\mathbf{6}$ could not be completely purified and characterized but it was clear from the ${ }^{1} \mathrm{H}$ NMR spectra of enriched mixtures (see Supplementary Information) that they were benzoate esters closely related to 4 . Main differences in the spectra (Table 1) could be attributed to a change in oxidation at $\mathrm{C}-7$. Thus, lack of the aldehyde resonance and a broad singlet $\left(\delta_{\mathrm{H}} 1.65,3 \mathrm{H}\right)$ in the spectrum of $\mathbf{5}$ suggested a vinyl methyl group at C-7, as in $\mathbf{3}$. This signal was not present in the spectrum of $\mathbf{6}$, but a new $2 \mathrm{H}$ broad singlet $\left(\delta_{\mathrm{H}} 4.01\right)$ could account for a primary alcohol group at C-7. Broadening of signals and slight shifts in resonances of ring protons, in comparison with $\mathbf{3}$, should arise from conformational changes of the cyclohexene ring due to the steric hindrance introduced by the ester aromatic ring. On this evidence $\mathbf{5}$ and $\mathbf{6}$ were tentatively identified as 9-benzoyloxy- $\alpha$-terpineol and 7-hydroxy-9benzoyloxy- $\alpha$-terpineol respectively. Compounds 2-6 have not been previously reported from natural sources and the proposed structures $\mathbf{3}, \mathbf{5}$ and $\mathbf{6}$, based only in the ${ }^{1} \mathrm{H}$ NMR analysis described, require further spectral studies to be fully established.

It is relevant to point out that 9-hydroxy- $\alpha$-terpineol derivatives have only been isolated from $H$. taeda and $H$. remyanus, as there is no report in the literature of this pattern of oxidation for $\alpha$-terpineol. This confirms a close genetic relationship among the two species found by Klingenberg in a recent revision of the phylogenetic of the genus, where she places both species in section Leiachaenium within a new sub genus Baylahuen. ${ }^{14}$

The flavonoid fraction of the extract $(\mathrm{F})$ was a complex mixture of flavonols and dihydroflavonoids, as seen by TLC. Repeated column chromatography and preparative chromatography led to the isolation of 7 and the partial purification of compounds 8-13 (Figure 2) ${ }^{1} \mathrm{H}$ NMR spectra were compared with spectroscopic data reported in the literature and led to the identification of quercetin (7), 3,7,4',-trimethylkaempferol (8) 7,4'-dimethylkaempferol (9), previously isolated from H. hirtellus ${ }^{15}$ and H. sonorensis, ${ }^{16}$ and the flavanones $7,4^{\prime}$-dimethylsakuranetin (12) and 7,4'-dimethylaromadendrin (13) also reported in $H$. baylahuen. ${ }^{17}$ TLC comparison with pure samples gave further support for the identification of these known flavonoids.

Compounds 10 and $\mathbf{1 1}$ were partially purified and analyzed their ${ }^{1} \mathrm{H}$ NMR spectra, but could not be fully characterized in this study. Both of them had a high field singlet $\left(\delta_{\mathrm{H}} 2.17\right.$ and 2.49 respectively, Table $\left.\mathrm{S} 1\right)$ that could be attributed to an acetate signal. Other signals in the spectra

Table 1. ${ }^{1} \mathrm{H}$ NMR data for 9-hydroxy- $\alpha$-terpineol derivatives 3-6 in $\mathrm{CDCl}_{3}{ }^{\mathrm{a}}$

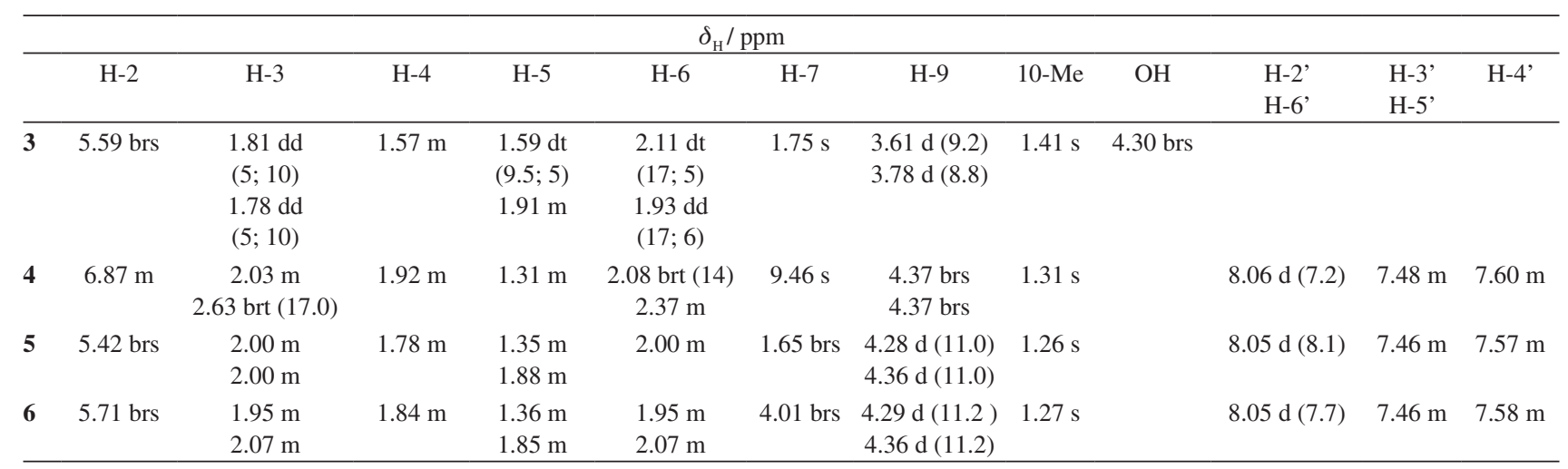

${ }^{\mathrm{a} A t} 400 \mathrm{MHz}, \mathrm{TMS}(\mathrm{J} \mathrm{Hz})$. 
<smiles>[R]c1cc(O)c2c(=O)c([R])c(-c3ccc([R])c([2H])c3)oc2c1</smiles>

$\begin{array}{ccccc} & \mathrm{R}^{1} & \mathrm{R}^{2} & \mathrm{R}^{3} & \mathrm{R}^{4} \\ 7 & \mathrm{OH} & \mathrm{OH} & \mathrm{OH} & \mathrm{OH} \\ 8 & \mathrm{OMe} & \mathrm{OMe} & \mathrm{H} & \mathrm{OMe} \\ 9 & \mathrm{OMe} & \mathrm{OMe} & \mathrm{H} & \mathrm{OH} \\ 10 & \mathrm{OMe} & \mathrm{OMe} & \mathrm{H} & \mathrm{OCOCH}_{3} \\ 11 & \mathrm{OMe} & \mathrm{OH} & \mathrm{OH} & \mathrm{OCOCH}_{3}\end{array}$<smiles>COc1ccc([C@H]2Oc3cc(OC)cc(O)c3C(=O)C2P)cc1</smiles>

Figure 2. Structures of flavonoids isolated from H. remyanus.

of $\mathbf{1 0}$ were consistent with a 7,4'-dimethylkaempferol skeleton and a 7-methylquercetin skeleton for $\mathbf{1 1}$. The position of the acetate at $\mathrm{C}-3$ was chosen by similarity with the flavanonol acetate previously reported in $\mathrm{H}$. remyanus. ${ }^{7}$ On this basis we propose structure $\mathbf{1 0}$ as 3-O-acetyl-7,4'dimethylkaempferol and 3-O-acetyl-7-methylquercetin for compound 11. Pinobanksin 3-acetate and pinostrobin, the main compounds previously reported from $H$. remyanus, ${ }^{7}$ were not detected in our extract.

Results of bioassays on the resin extract showed moderate but significant anti-inflammatory activity $(23.4 \pm 2.5 \%)$ at the concentration used ( $3 \mathrm{mg}$ per ear). On the other hand, the cytotoxic activity displayed by the extract was dose dependent (Figure 3) and moderate in comparison to doxorubicin (anti neoplastic agent) at a similar concentration.

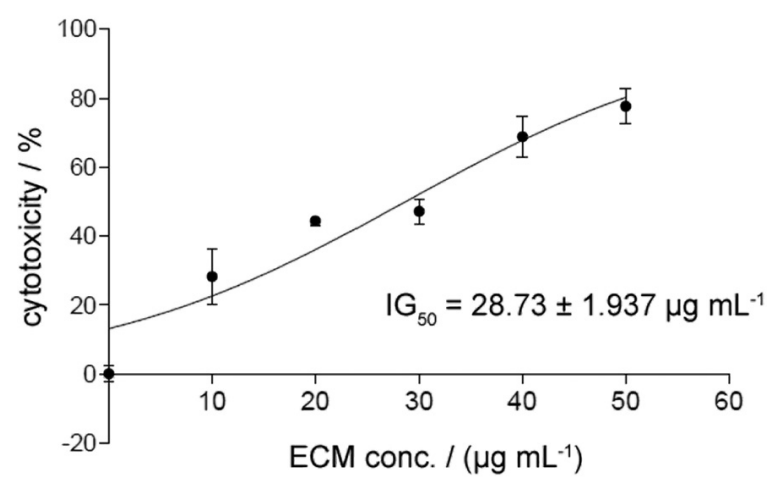

Figure 3. Cytotoxicity of $H$. remyanus extract towards T-lymphoblastic leukemia cell line (CCRF-CEM) using the MTT-microculture tetrazolium assay. Doxorubicin used as standard showed $\mathrm{IG}_{50}=0.0179 \mu \mathrm{g} \mathrm{mL}-1$.

Although a thorough characterization and purification of the compounds reported in this study could not be completely achieved due to the complexity of the mixtures, it was clear from the analysis that this extract of $H$. remyanus was different in chemical composition to that reported by Zdero et al. ${ }^{7}$ from the same plant. Main significant differences among the results of both studies are in the structures of the flavonoids isolated in each case. Variations in chemical composition and bioactivity within a same species are not unusual, as the elaboration of secondary metabolites in a plant is closely related to the environmental conditions predominating in their habitat (oxidative stress, parasitism, etc). However, the impact of these chemical differences on the medicinal properties of a species cannot be overlooked, as the concentrations of the active principles correlate directly with their therapeutic effect.

Thus, the previously reported high radical scavenging activity displayed by $H$. remyanus extract in the DPPH bioassay ${ }^{4}$ can now be explained by the presence of flavonoids 7-11. ${ }^{8}$ On the other hand, the anti-inflammatory activity in the ear edema bioassay, could arise in part from quercetin and kaempferol derivatives detected in this study, as well as the dihydroflavonoids, as reported in the literature. ${ }^{18,19} \mathrm{~A}$ characteristic feature in the flavonoids isolated from medicinal Haplopappus species studied so far is the presence of a methyl ether at C-7. Methylation in flavones has been found to be important in terms of oral administration of cancer chemopreventives, as their bio availability is higher than the unmethylated analogs. ${ }^{20}$ Methylation at C-3 is also regarded to enhance the antiinflammatory activity of quercetin. ${ }^{21}$

The possible role of monoterpene derivatives 3-6 in the bioactivity of the extract was not established and further studies are necessary in order to assess their antiinflammatory and antiproliferative activities. In this sense, it has been recently reported that $\alpha$-terpineol has low activity in the DPPH assay although it has an ORAC value similar to that of BHA, used in food preservation..$^{22}$ Other studies report that $\alpha$-terpineol has in vitro antiproliferative activity, inhibits lipid peroxidation and reduces the release of superoxide anions by cultured leukemic cells. ${ }^{23}$ These biological activities could be associated with the presence of the tertiary hydroxyl group attached to C-8, as $\alpha$-terpineol was more active than limonene, carvone and perillyl alcohol in these experiments. ${ }^{22,23}$ It is then plausible to expect that the 9-hydroxy derivatives 3-6 would share some of the bioactivities described for $\alpha$-terpineol. 


\section{Conclusions}

H. remyanus produces 7-O-methyl-flavonoids, and characteristic 9-hydroxy $\alpha$-terpineol esters, and thus differentiates from other "bailahuen" species that accumulate coumarins and/or diterpenoids. Intraspecific chemical variations in extract composition were detected in comparison with a previous report, ${ }^{7}$ suggesting the existence of at least two ecotypes for $H$. remyanus. Due to the characteristic coloration of the aldehyde $\mathbf{4}$ on TLC, this compound could be easily detected and used as a chemical marker for the identification of the ecotype analyzed, in the present study. On the other hand, the elaboration of unique 9-hydroxy- $\alpha$ terpineol derivatives confirms the close genetical relationship with $H$. taeda, reported in recent botanical studies. ${ }^{14}$

The results of anti-inflammatory, antioxidant and cytotoxic bioassays of extracts of $H$. remyanus show moderate but relevant activity that can be attributed mainly to flavonoids $\mathbf{7 - 1 3}$. Thus, a partial purification of the extract should enhance the topical anti-inflammatory activity detected in bioassays. In addition to these results, a high concentration of the bioactive flavanone pinostrobin ${ }^{24}$ in the ecotype studied by Zdero et al..$^{7}$ provides further support for the therapeutic uses of $H$. remyanus. The possible contribution of monoterpene derivatives (3-6) to the bioactivity of the extract has yet to be established.

Finally, due to the high yield (13.4\% in dry leaves) of resinous exudate, $H$. remyanus could be considered a good potential source of bioactive compounds.

\section{Supplementary Information}

NMR spectra (Figures S1-S14) are available free of charge at http://jbcs.sbq.org.br as PDF file.

\section{Acknowledgments}

Financial support from FONDECYT (P1030813), DICYT-USACH, Facultad de Ciencias (Universidad de Chile), and the assistance of Dr. Federico Luebert in collecting and identifying the plant material are gratefully acknowledged.

\section{References}

1. Marticorena, C.; Quezada, M.; Gayana Botanica 1985, 42, 157.

2. Muñoz, M.; Barrera, E.; Meza, I.; Publicación Ocasional N. 33, Museo Nacional de Historia Natural; 1981, p. 29. http:// www.graficanimada.cl/sinab/publi-ocacional.html accessed in July 2011.

3. Urzúa, A.; Torres, R.; Palacios, Y; J. Ethnopharmacol. 1995, 45,71 .
4. Vogel, H.; González, M.; Faini, F.; Razmilic, I.; Rodríguez, J.; San Martín, J.; Urbina, F.; J. Ethnopharmacol. 2005, 97, 97.

5. Faini, F.; Labbé, C.; Torres, R.; Rodilla, J. M.; Silva, L.; Delle Monache, F.; Fitoterapia 2007, 78, 611.

6. Torres, R.; Faini, F.; Modak, B.; Urbina, F.; Labbé, C.; Guerrero, J.; Phytochemistry 2006, 67, 984.

7. Zdero, C.; Bohlmann, F.; Niemeyer, H. M.; Phytochemistry 1991, 30, 3669.

8. Seyoum, A.; Asres, K.; El-Fiky, F.; Phytochemistry 2006, 67, 2058.

9. Guey-Mei, J.; Cheng-Jen, C.; Bing-Fang, C.; Jia-Huei, T.; Cancer Lett. 2004, 216, 165.

10. Yuanbin, L.; Peterson, D. A.; Kimcera, H.; Schubert, D.; J. Neurochem. 1997, 69, 5.

11. Sanmartín, C.; Plano, D.; Domínguez, E.; Font, M.; Calvo, A.; Prior, C.; Encío, I.; Palop, J. A.; Molecules 2009, 14, 3313.

12. Lloret, S.; Moreno, J.; Biochem. Pharmacol. 1995, 50, 347.

13. Delporte, C.; Backhouse, N.; Erazo, S.; Negrete, R.; Vidal, P.; Silva, X.; López-Pérez, J.; San Feliciano, A.; Muñoz, O.; J. Ethnopharmacol. 2005, 99, 119.

14. Klingenberg, L.; Monographie der südamerikanischen Gattungen Haplopappus Cass. und Notopappus L. Klingenberg (Asteraceae-Astereae), E. Schweizerbart'sche Verlagsbuchhandlung (Nägele u. Obermiller), Science Publishers: Stuttgart, 2011. http://www.nhbs.com/monographie_ der_s_tefno_154871.html accessed in July 2011.

15. Maldonado, Z.; Hoeneisen, M.; Silva, M.; Bol. Soc. Chil. Quim. 1993, 38, 43.

16. Murillo, J. I.; Encarnación-Dimayuga, R.; Malmstrøm, J.; Christophersen, C.; Franzblau, S. G.; Fitoterapia 2003, 74, 226.

17. Nuñez-Alarcón, J.; Dolz, H.; Quiñones, M.; Carmona, M.; Bol. Soc. Chil. Quim. 1993, 38, 15.

18. Morikawa, K.; Nonaka, M.; Narahara, M.; Torii, J.; Kawaguchi, K.; Takafumi, Y.; Kumazawa, Y.; Morikawa, S.; Life Sci. 2003, 74, 709 .

19. Hernández, V.; Recio, M.C.; Máñez, S.; Giner, R. M.; Ríos, J. L.; Life Sci. 2007, 81, 480.

20. Walle, T.; Ta, N.; Kawamori, T.; Wen, X.; Tsuji, P.; Walle, U. K.; Biochem. Pharmacol. 2007, 73, 1288.

21. Krenn, L.; Wollenweber, E.; Steyrleuthner, K.; Görick, C.; Melzig, M.; Fitoterapia 2009, 80, 267.

22. Junior, M.; Silva, T.; Franchi, G.; Nowill, A.; Pastore, G.; Hyslop, S.; Food Chem. 2009, 116, 8.

23. Bicas, J. L.; Neri-Numa, I. A.; Ruiz, A. L. T. G.; De Carvalho, J. E.; Pastore, G. M.; Food Chem. Toxicol. 2011, 49, 1610.

24. Abdelwahab, S. I.; Mohan, S.; Abdulla, M. A.; Sukari, M. A.; Abdul, A. B.; Taha, M.; Syam, S.; Ahmad, S.; Lee, K.; J. Ethnopharmacol. 2011, 137, 963.

Submitted: April 1, 2011 Published online: October 27, 2011 


\section{Chemistry and Bioactivity of Haplopappus remyanus ("bailahuen"), a Chilean Medicinal Plant}

Francesca Faini, ${ }^{*, a}$ René Torres, ${ }^{b}$ Jesús M. Rodilla, ${ }^{c}$ Cecilia Labbé, ${ }^{a}$ Carla Delported and Fabián Jaña ${ }^{a}$

${ }^{a}$ Departamento de Química, Facultad de Ciencias and ${ }^{d}$ Departamento de Química Farmacológica y Toxicológica, Facultad de Ciencias Químicas y Farmacéuticas, Universidad de Chile, Santiago,Chile

${ }^{b}$ Departamento de Ciencias del Ambiente, Facultad de Química y Biología, Universidad de Santiago, Santiago, Chile

${ }^{c}$ Departamento de Química, Universidade da Beira Interior, 6201-001 Covilha, Portugal

${ }^{1}$ H NMR spectra of compounds (Table S1 and Figures S1-S14)

Table S1. ${ }^{1} \mathrm{H}$ NMR of flavonoids 8-13 at $400 \mathrm{MHz}$ in $\mathrm{CDCl}_{3}(J, \mathrm{~Hz})$

\begin{tabular}{|c|c|c|c|c|c|c|c|c|c|c|c|}
\hline \multicolumn{12}{|c|}{$\delta_{\mathrm{H}} / \mathrm{ppm}$} \\
\hline & $\mathrm{H}-2$ & $\mathrm{H}-3$ & H-6 & H-8 & $\begin{array}{l}\text { H-2' } \\
\text { H-6, }\end{array}$ & $\begin{array}{l}\text { H-3' } \\
\text { H-5 }\end{array}$ & 7-OMe & 3-OMe & 4'-OMe & $\mathrm{OH}$ & OAc \\
\hline 8 & & & $\begin{array}{c}6.36 \mathrm{~d} \\
(2.3)\end{array}$ & $\begin{array}{l}6.45 \mathrm{~d} \\
(2.04)\end{array}$ & $\begin{array}{c}8.09 \mathrm{~d} \\
(9.1)\end{array}$ & $\begin{array}{c}7.03 \mathrm{~d} \\
(9.1)\end{array}$ & 3.86 & 3.91 & 3.88 & & \\
\hline 9 & & & $6.38 \mathrm{~s}$ & $6.49 \mathrm{~s}$ & $\begin{array}{c}8.18 \mathrm{~d} \\
(8.7)\end{array}$ & $\begin{array}{c}7.04 \mathrm{~d} \\
(9.3)\end{array}$ & 3.90 & & 3.89 & 6.66 brs & \\
\hline 10 & & & $\begin{array}{c}6.31 \mathrm{~d} \\
(1.8)\end{array}$ & $\begin{array}{c}6.41 \mathrm{~d} \\
(2.2)\end{array}$ & $\begin{array}{c}8.06 \mathrm{~d} \\
(8.8)\end{array}$ & $\begin{array}{c}7.03 \mathrm{~d} \\
(8.8)\end{array}$ & 3.89 & & 3.84 & 12.66 & $2.17 \mathrm{~s}$ \\
\hline 11 & & & $\begin{array}{c}6.31 \mathrm{~d} \\
(2.0)\end{array}$ & $\begin{array}{c}6.39 \mathrm{~d} \\
(2.0)\end{array}$ & $\begin{array}{c}7.71 \mathrm{~d} \\
(2.0) \\
7.56 \mathrm{dd}, \\
(8.5,2.0)\end{array}$ & $\begin{array}{l}6.85 \mathrm{~d} \\
(8.5)\end{array}$ & 3.79 & & & $\begin{array}{c}12.10 \\
8.0 \\
8.45 \text { brs }\end{array}$ & $2.49 \mathrm{~s}$ \\
\hline 12 & $\begin{array}{c}5.37 \mathrm{dd} \\
(13 ; 2.7)\end{array}$ & $\begin{array}{c}2.79 \mathrm{dd} \\
(17.2 ; 12.8) \\
3.11 \mathrm{dd} \\
(17.2 ; 2.9)\end{array}$ & $\begin{array}{c}6.05 \mathrm{~d} \\
(2.3)\end{array}$ & $\begin{array}{c}6.07 \mathrm{~d} \\
(2.5)\end{array}$ & $\begin{array}{c}7.39 \mathrm{~d} \\
(8.7)\end{array}$ & $\begin{array}{c}6.96 \mathrm{~d} \\
(8.7)\end{array}$ & 3.81 & & 3.84 & 12.03 & \\
\hline 13 & $\begin{array}{l}5.07 \mathrm{~d} \\
(11.9)\end{array}$ & $\begin{array}{l}4.59 \mathrm{~d} \\
(11.9)\end{array}$ & $\begin{array}{c}6.08 \mathrm{~d} \\
(1.8)\end{array}$ & $\begin{array}{c}6.15 \mathrm{~d} \\
(2.3)\end{array}$ & $\begin{array}{l}7.51 \mathrm{~d} \\
(8.6)\end{array}$ & $\begin{array}{c}7.02 \mathrm{~d} \\
(8.6)\end{array}$ & 3.87 & & 3.84 & $\begin{array}{l}3.48, \\
11.22\end{array}$ & \\
\hline
\end{tabular}

*e-mail: ffaini@uchile.cl 


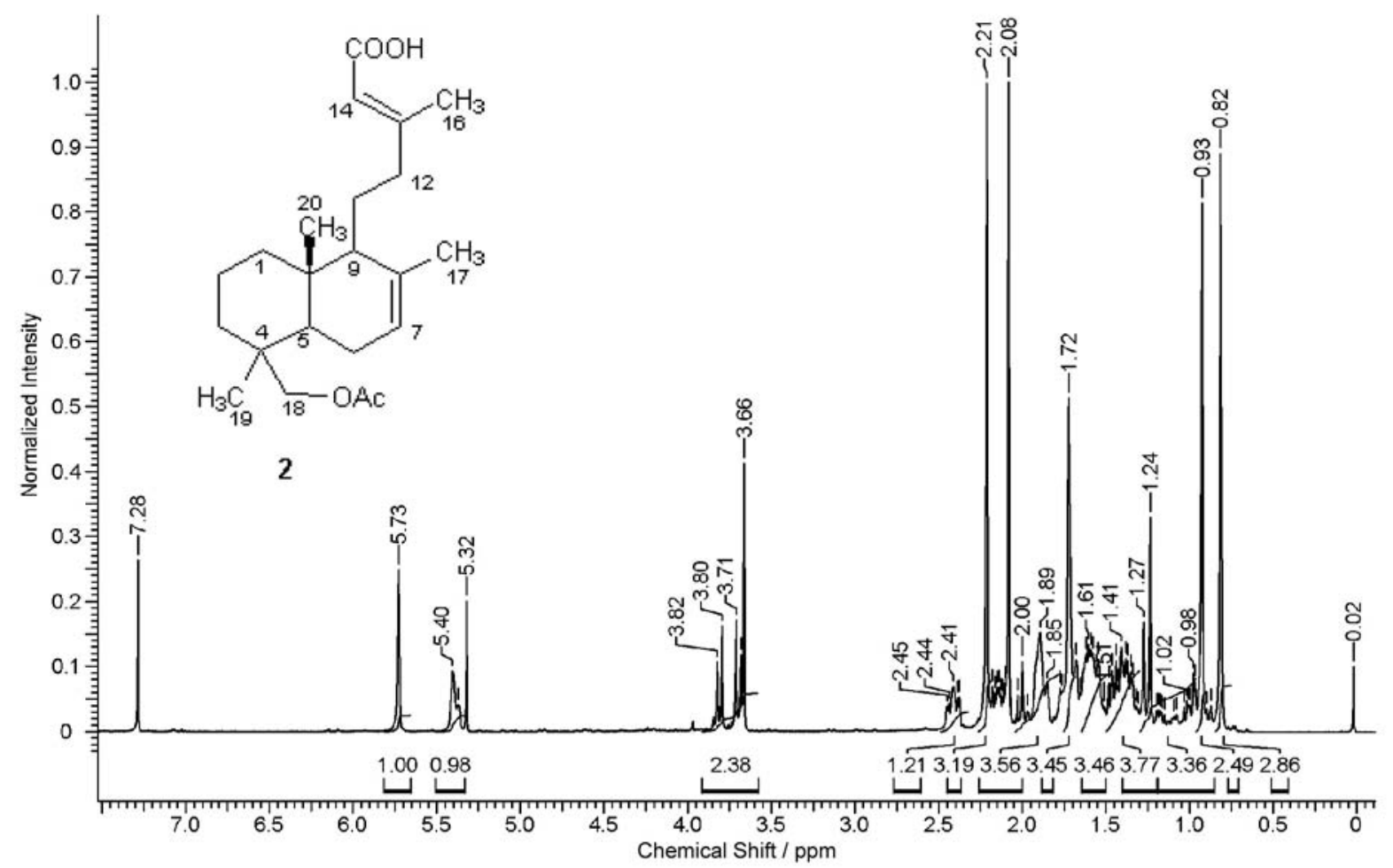

Figure S1. ${ }^{1} \mathrm{H}$ NMR spectrum of compound 2, in $\mathrm{CDCl}_{3}$.

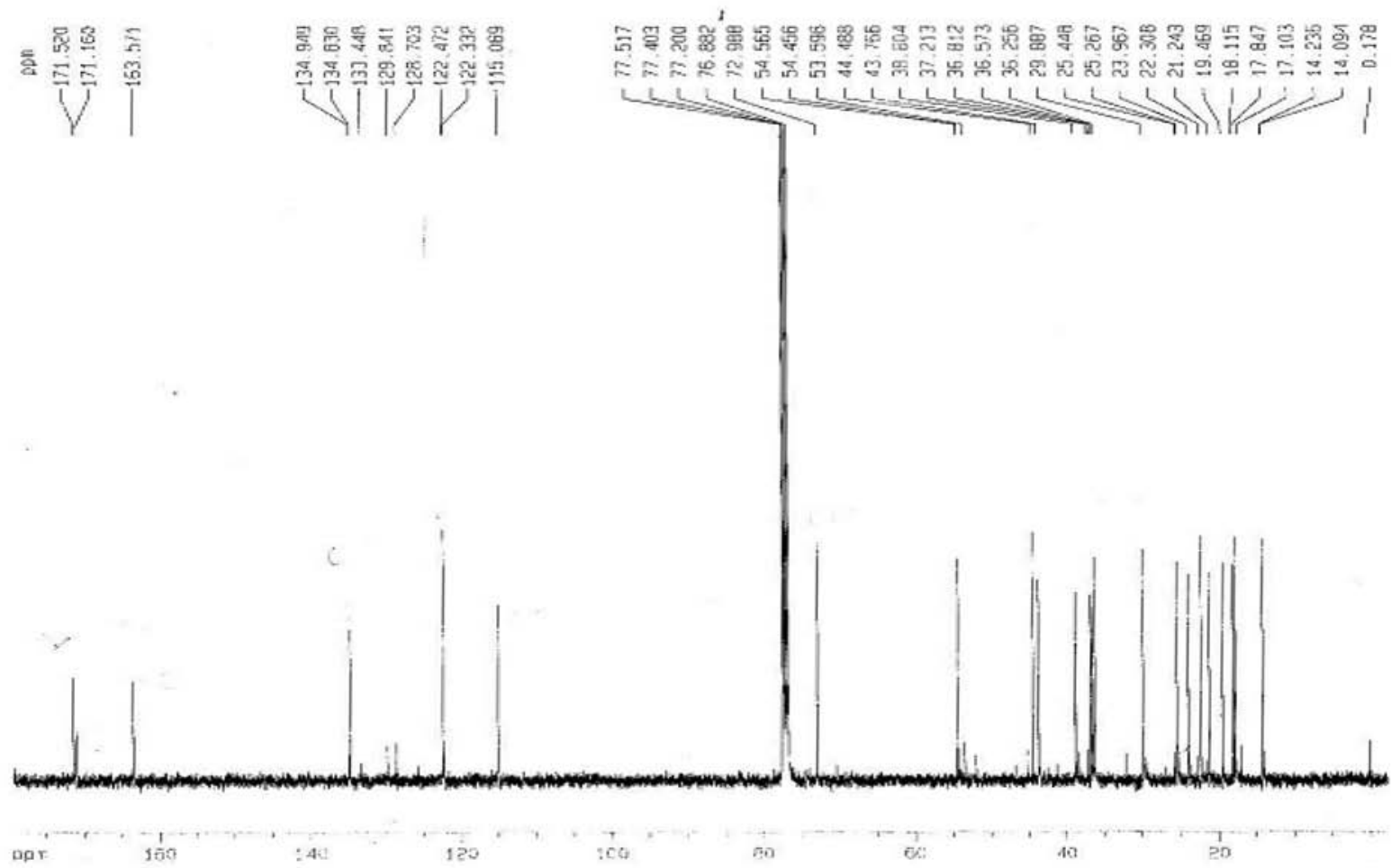

Figure S2. ${ }^{13} \mathrm{C}$ NMR spectrum of compound 2, in $\mathrm{CDCl}_{3}$. 


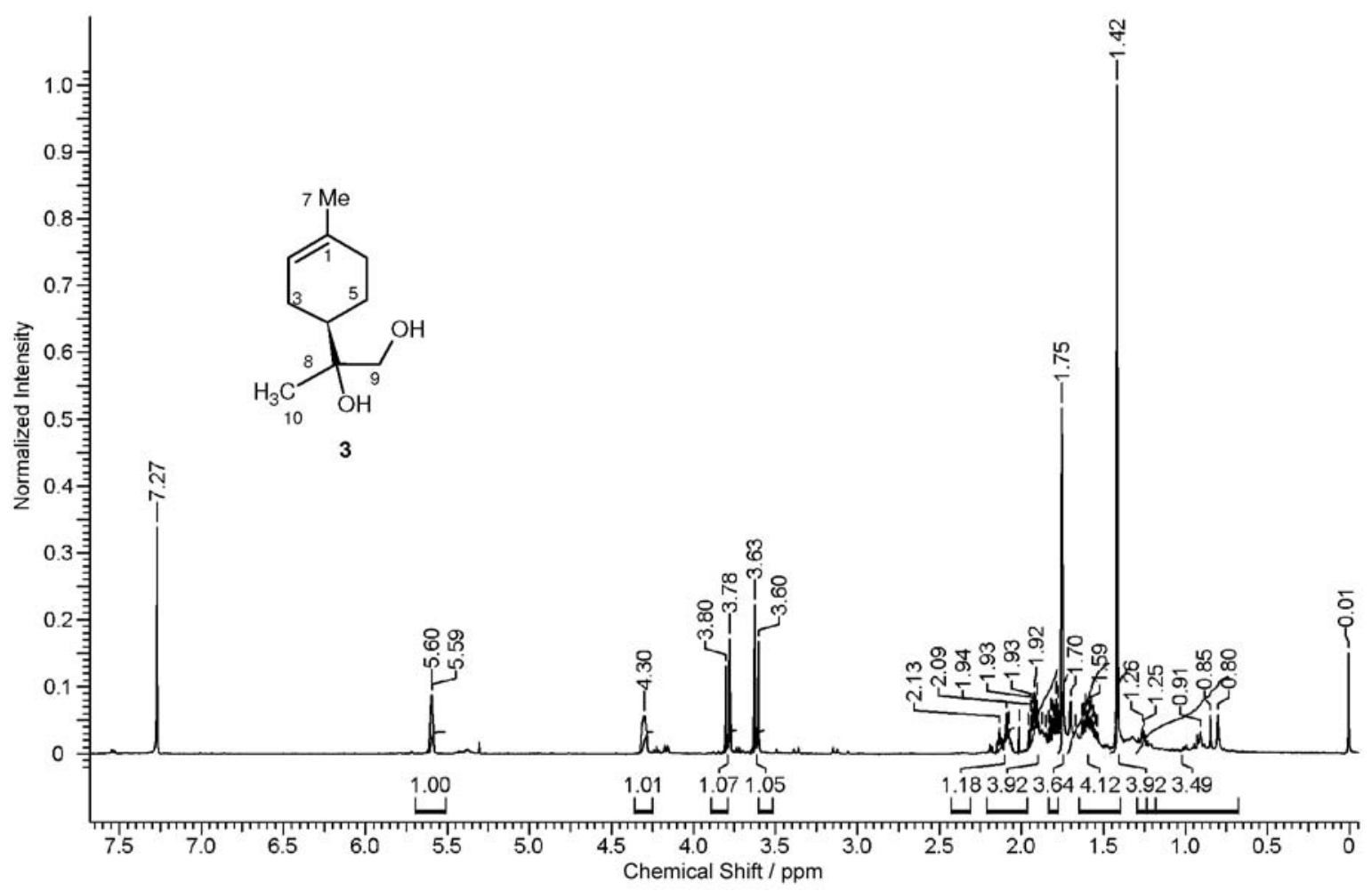

Figure S3. ${ }^{1} \mathrm{H}$ NMR spectrum of compound 3 , in $\mathrm{CDCl}_{3}$.<smiles>CC(O)(COC(=O)O)[C@H]1CC=C(C=O)CC1</smiles>

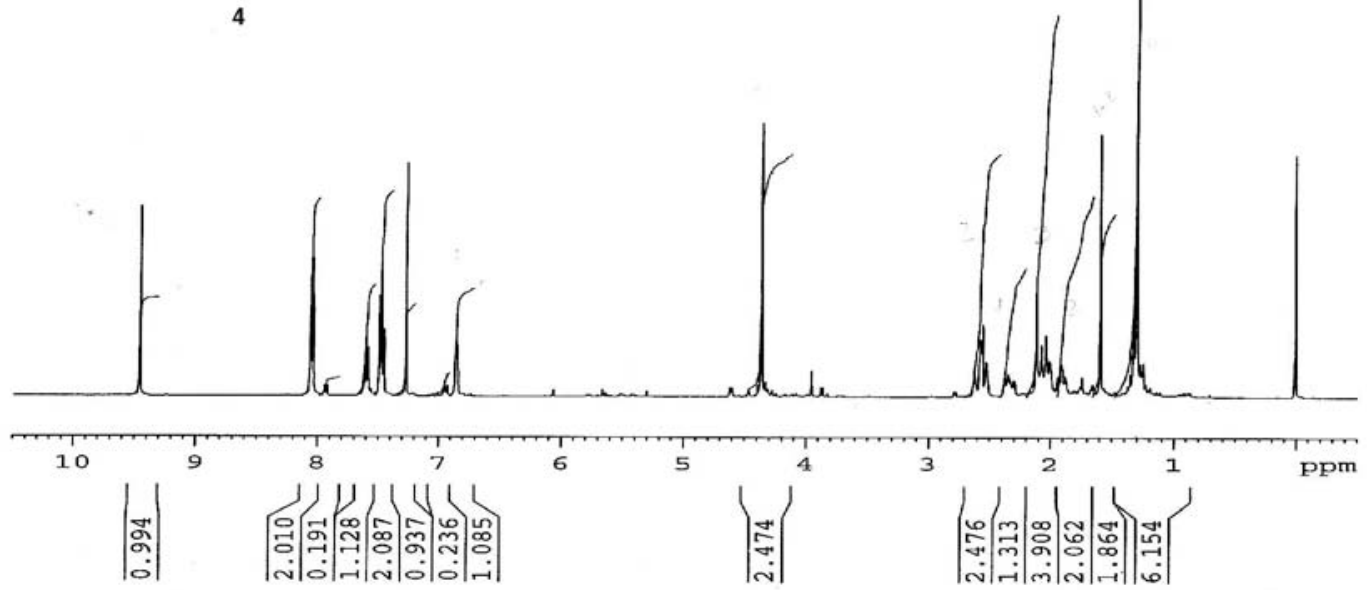

Figure S4. 'H NMR spectrum of compound $\mathbf{4}$, in $\mathrm{CDCl}_{3}$. 

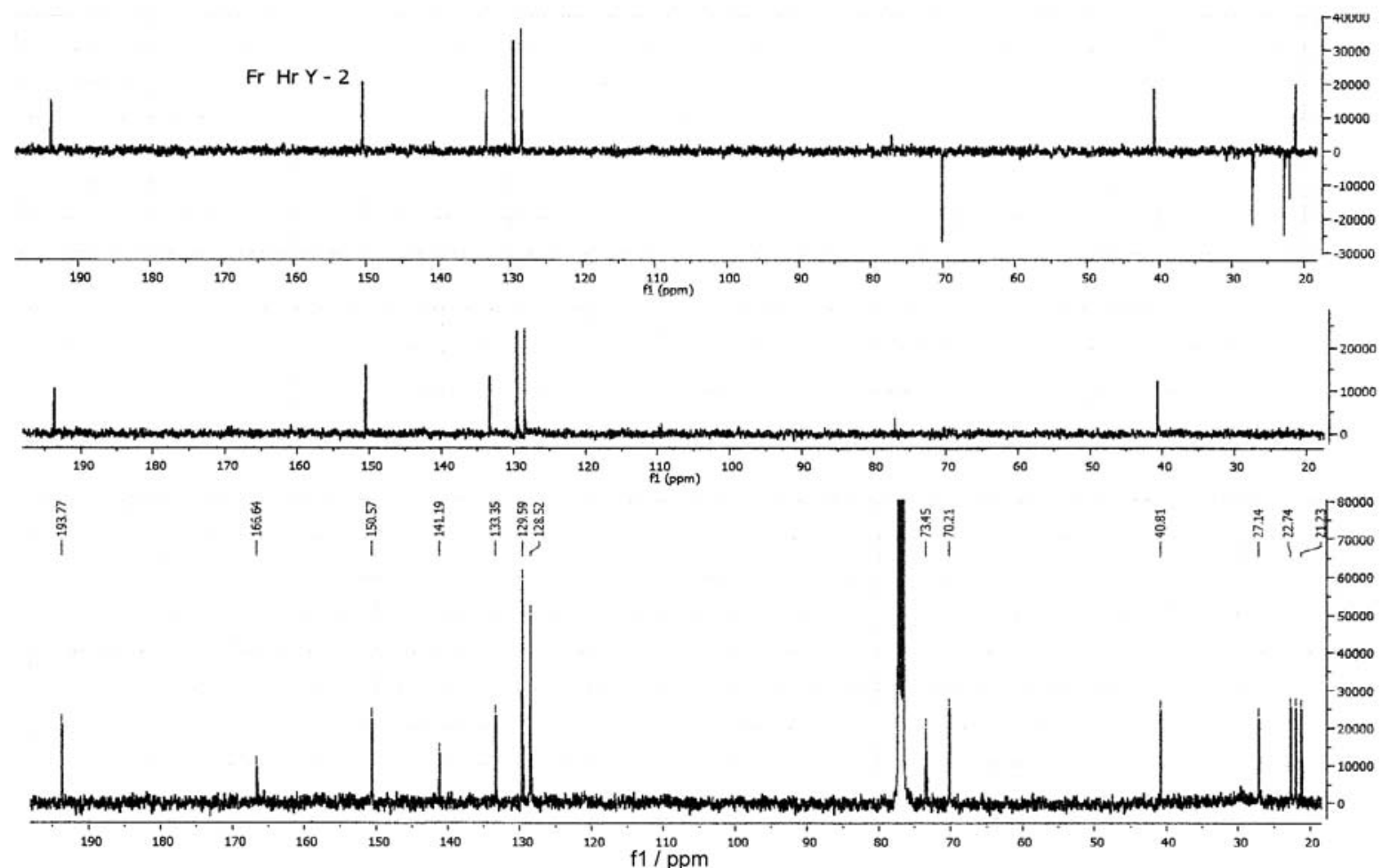

Figure S5. ${ }^{13} \mathrm{C}$ NMR spectra of compound 4 , in $\mathrm{CDCl}_{3}$.

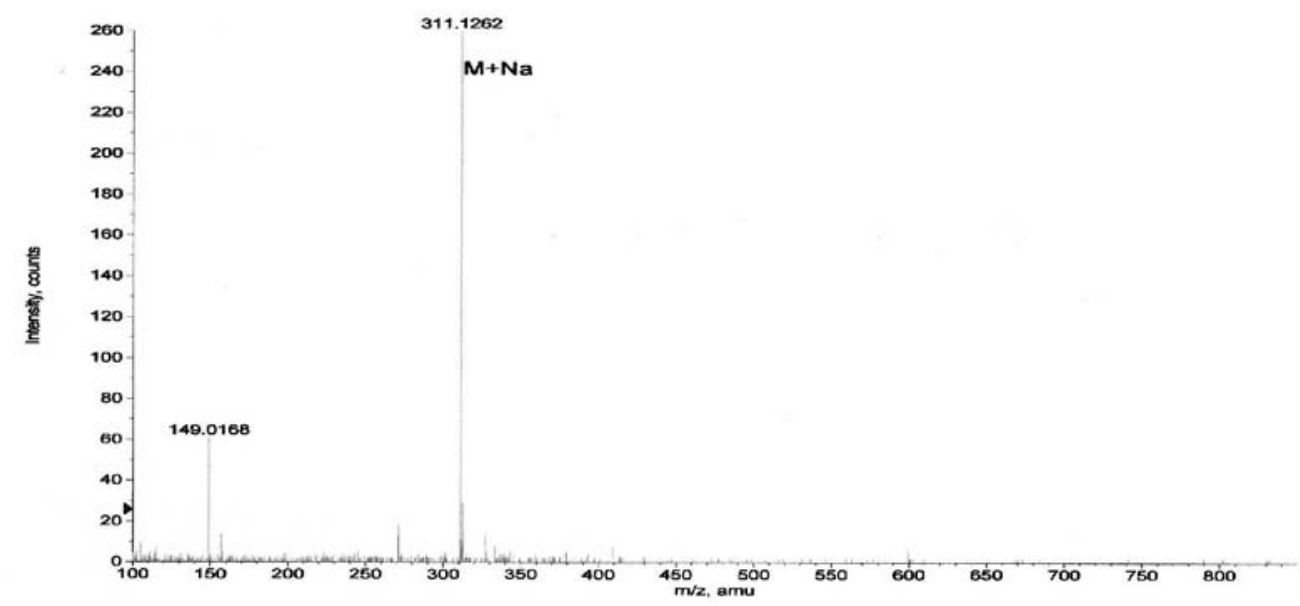

\begin{tabular}{lrrrr}
\hline Formula & CalculatedMass & mDaError & \multicolumn{1}{r}{ PpmError } & \multicolumn{1}{r}{ RDB } \\
\hline C2 H16 N12 O5 Na & 311.125883 & 0.316944 & 1.018697 & 0.5 \\
C18 H16 N4 Na & 311.126718 & -0.517792 & -1.664248 & 12.5 \\
H11 N18 O3 & 311.125603 & 0.597076 & 1.919076 & 4.5 \\
C17 H20 O4 Na & 311.12538 & 0.81952 & 2.634039 & 7.5 \\
C3 H12 N16 O Na & 311.12722 & -1.020368 & -3.279589 & 5.5 \\
C15 H15 N6 O2 & 311.1251 & 1.099652 & 3.534418 & 11.5 \\
C19 H19 O4 & 311.127786 & -1.58574 & -5.096765 & 10.5 \\
C4 H15 N12 O5 & 311.128288 & -2.088316 & -6.712107 & 3.5 \\
C6 H20 N6 O7 Na & 311.128568 & -2.368448 & -7.612486 & -0.5 \\
C14 H19 N2 O6 & 311.123763 & 2.436964 & 7.832705 & 6.5 \\
C20 H15 N4 & 311.129123 & -2.923052 & -9.395052 & 15.5
\end{tabular}

Figure S6. TOF mass spectrum of compound 4. 

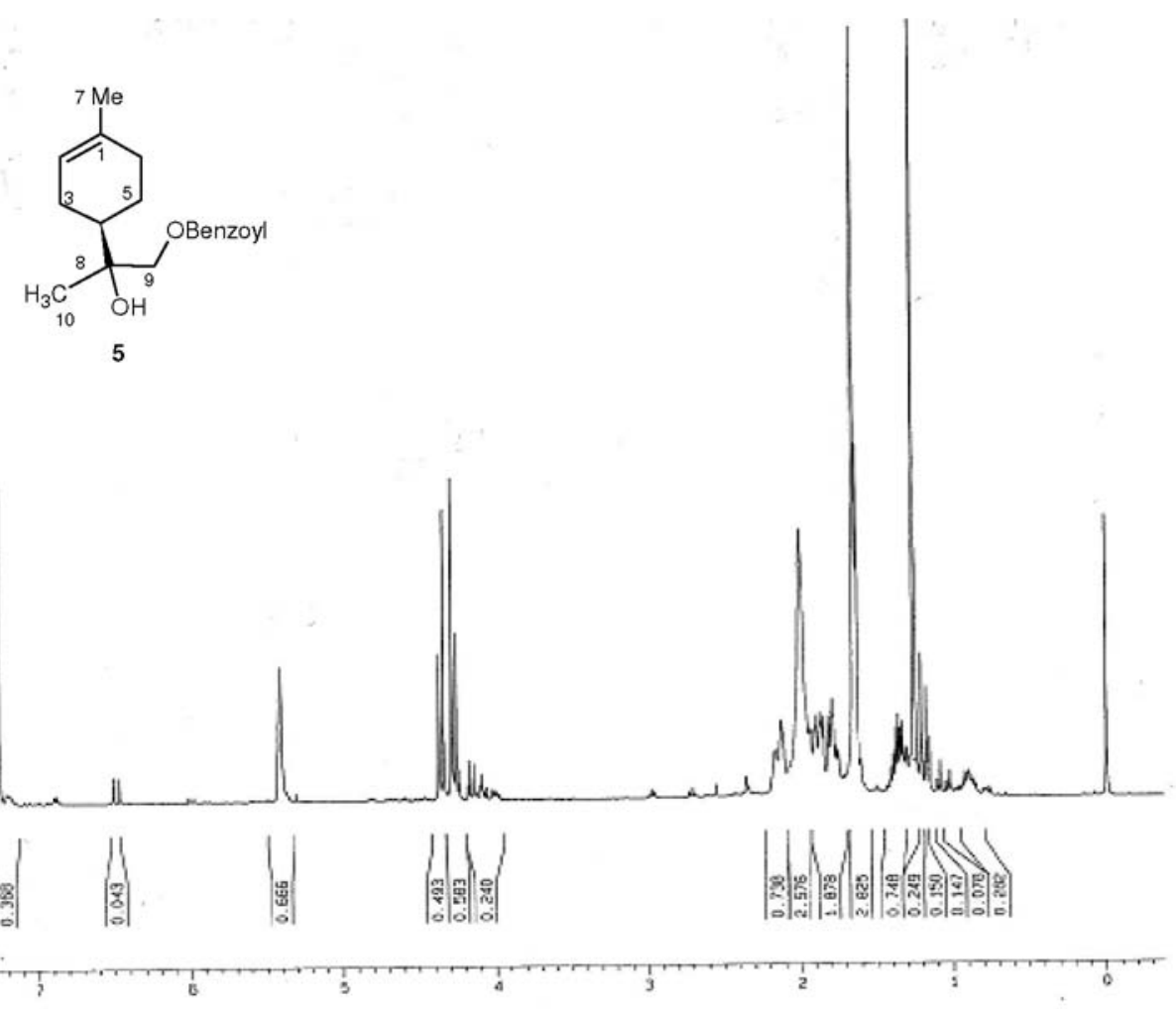

Figure S7. ${ }^{1} \mathrm{H}$ NMR spectrum of compound $\mathbf{5}$, in $\mathrm{CDCl}_{3}$.
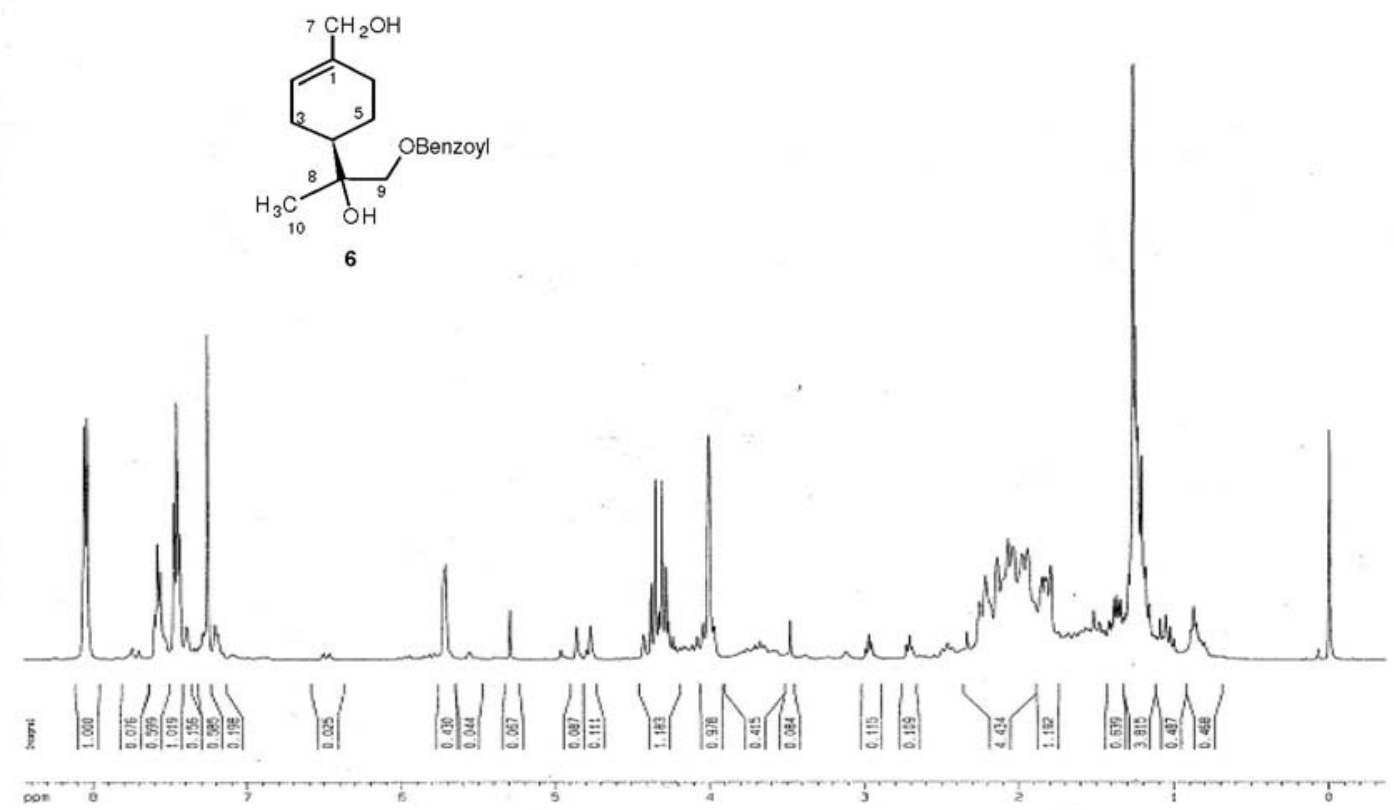

Figure S8. ${ }^{1} \mathrm{H}$ NMR spectrum of compound $\mathbf{6}$, in $\mathrm{CDCl}_{3}$. 


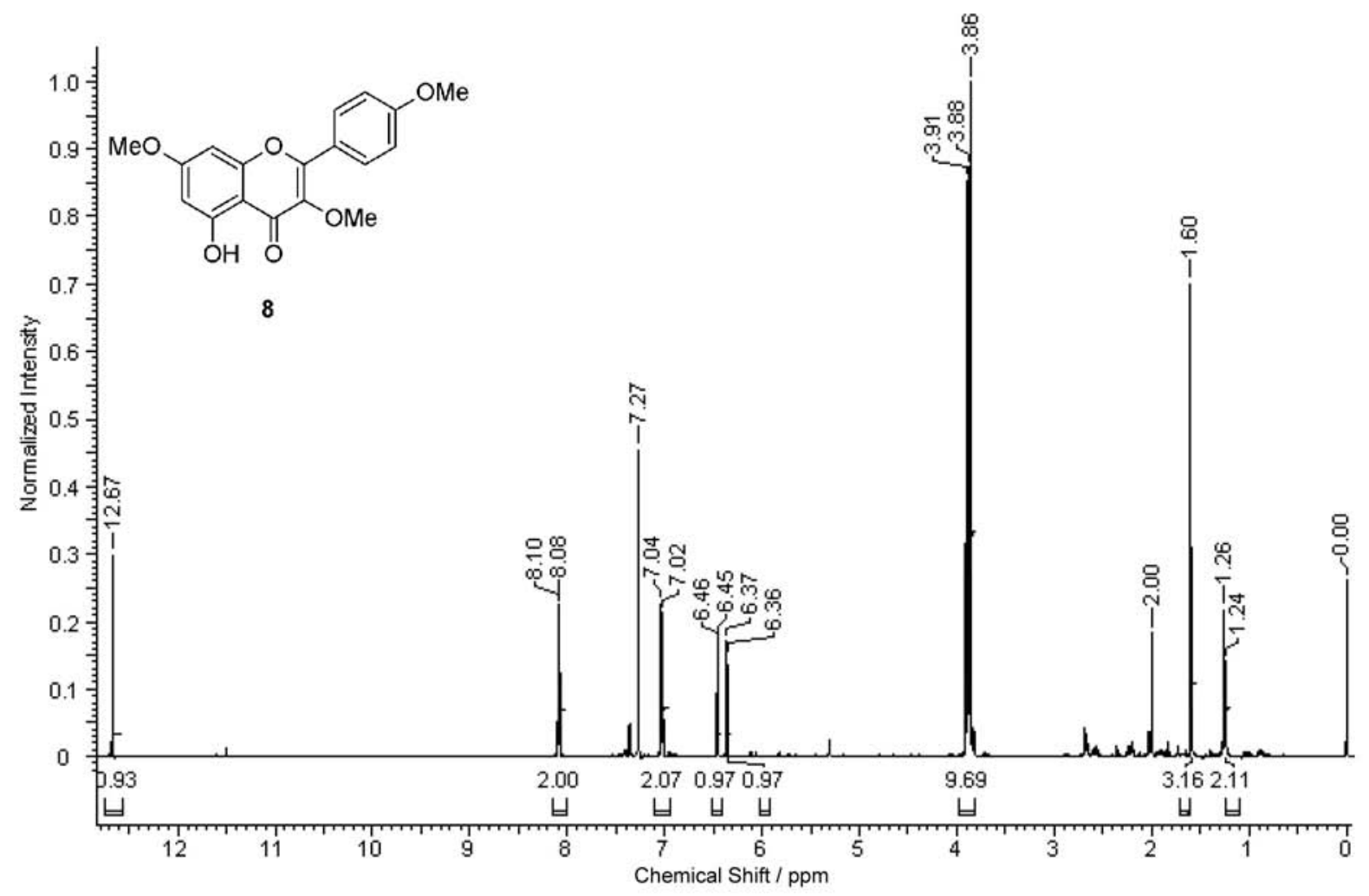

Figure S9. ${ }^{1} \mathrm{H}$ NMR spectrum of compound $\mathbf{8}$, in $\mathrm{CDCl}_{3}$.

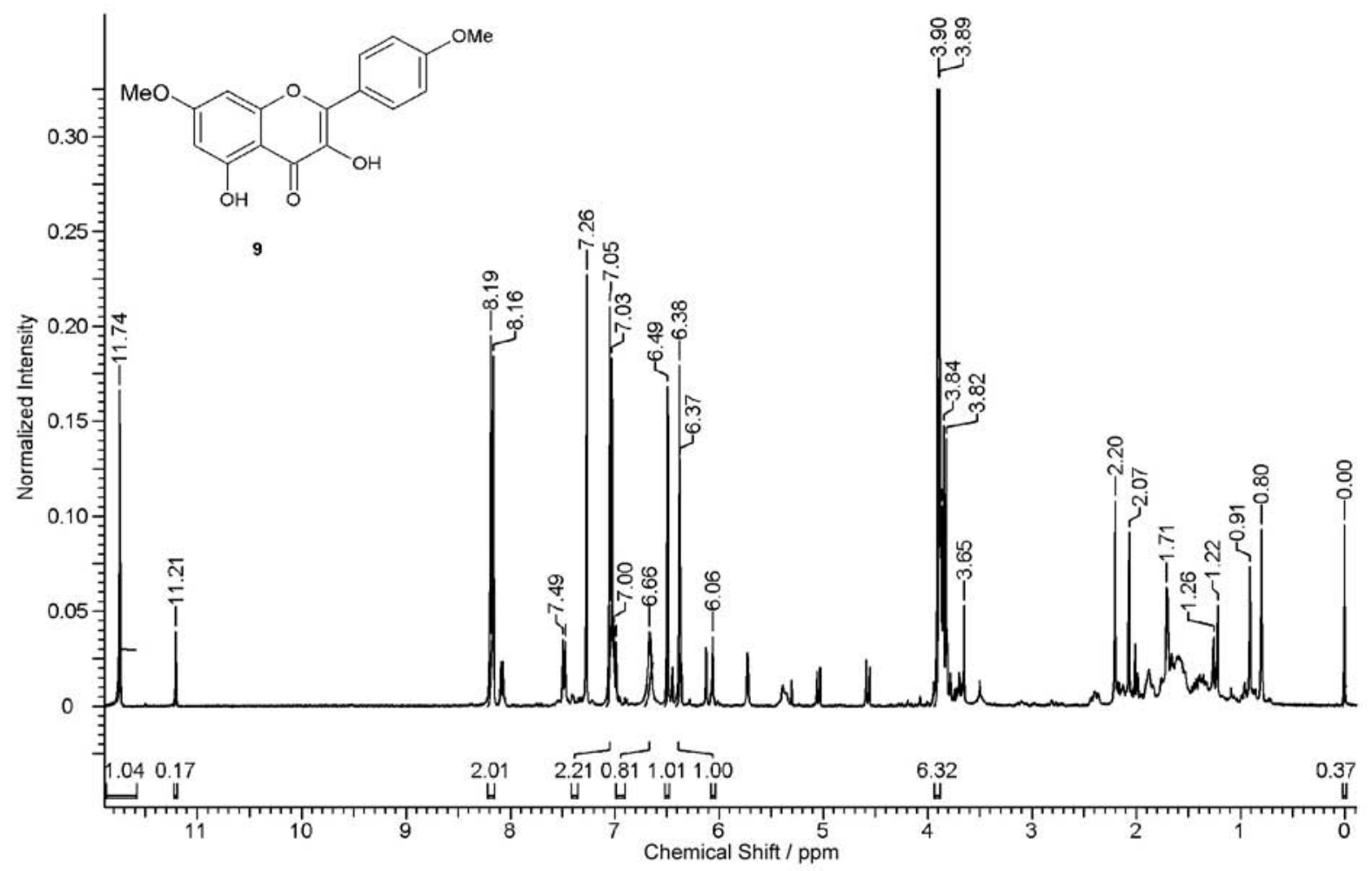

Figure S10. ${ }^{~} \mathrm{H}$ NMR spectrum of compound $\mathbf{9}$, in $\mathrm{CDCl}_{3}$. 


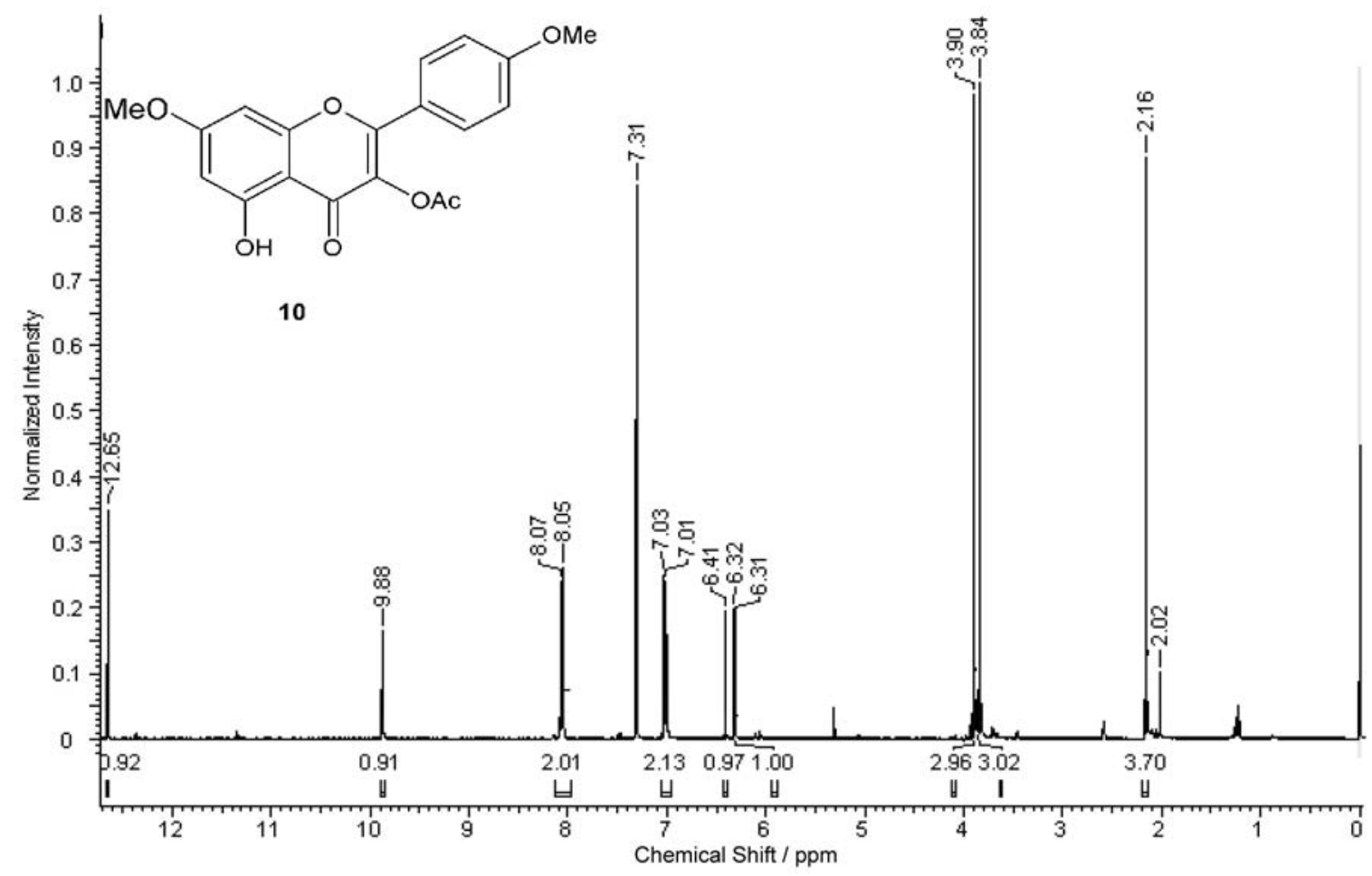

Figure S11. ${ }^{1} \mathrm{H}$ NMR spectrum of compound 10, in $\mathrm{CDCl}_{3}$.

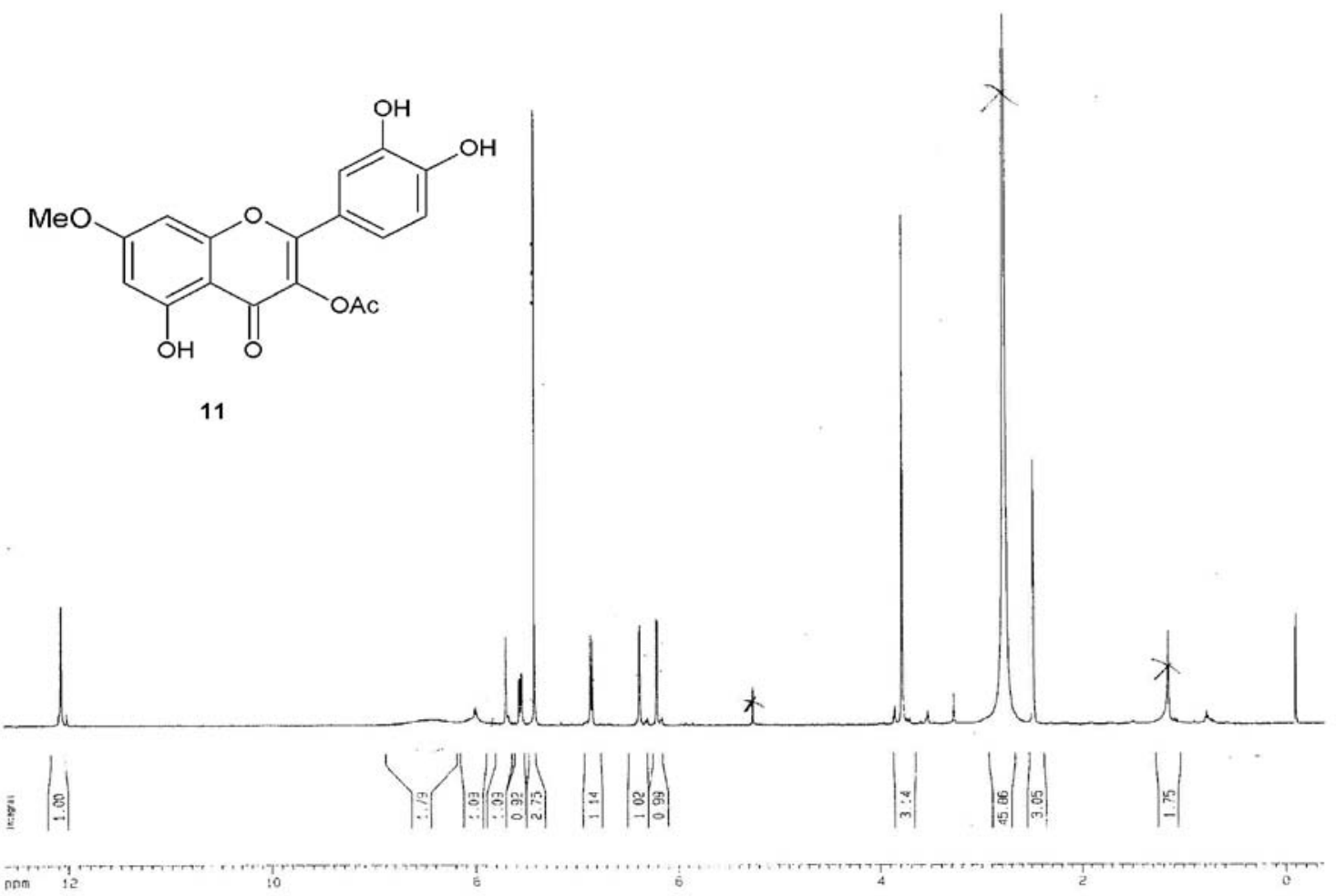

Figure S12. ${ }^{1} \mathrm{H}$ NMR spectrum of compound 11, in $\mathrm{CDCl}_{3}$. 


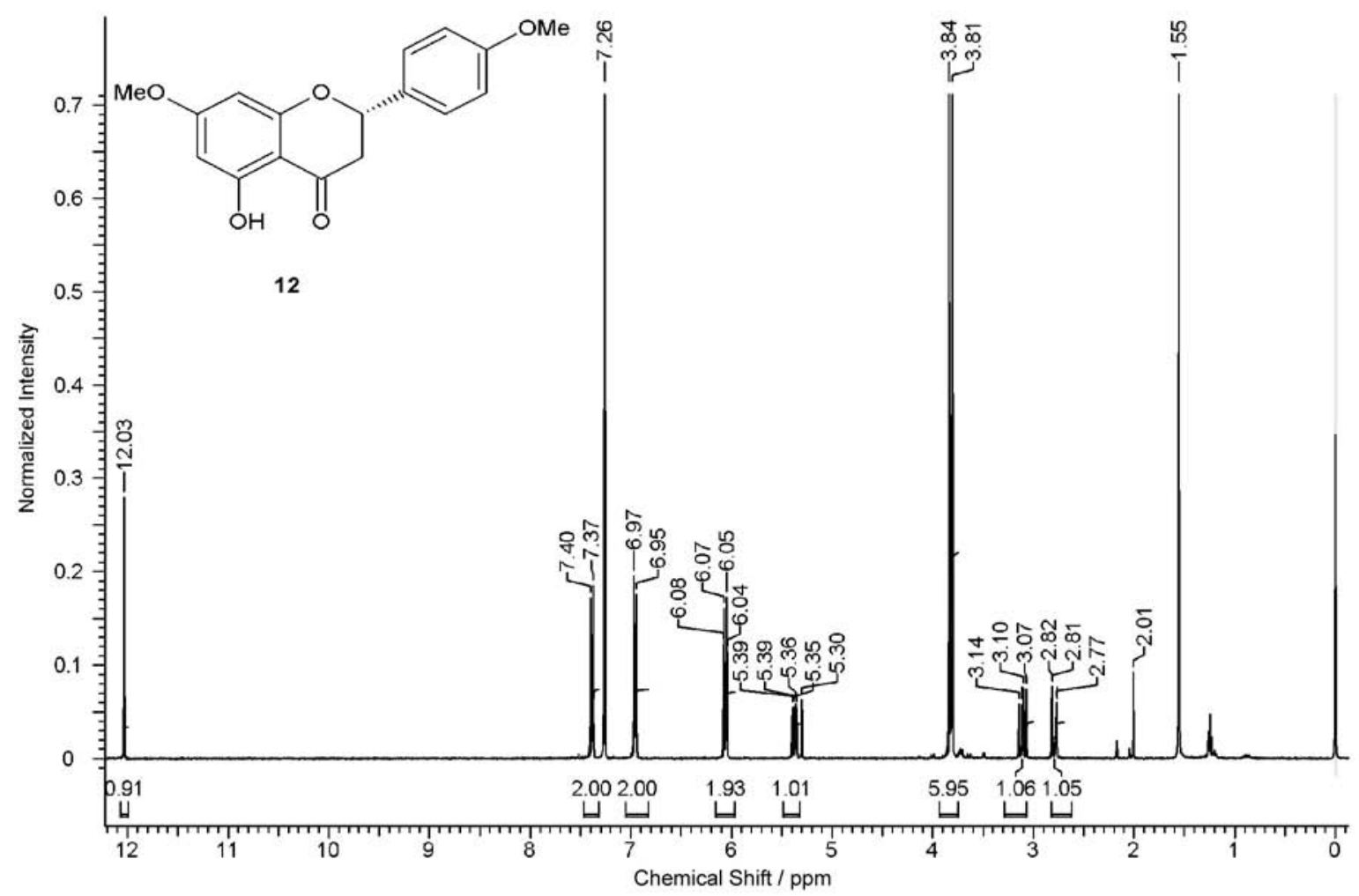

Figure S13. ${ }^{1} \mathrm{H}$ NMR spectrum of compound 12, in $\mathrm{CDCl}_{3}$.

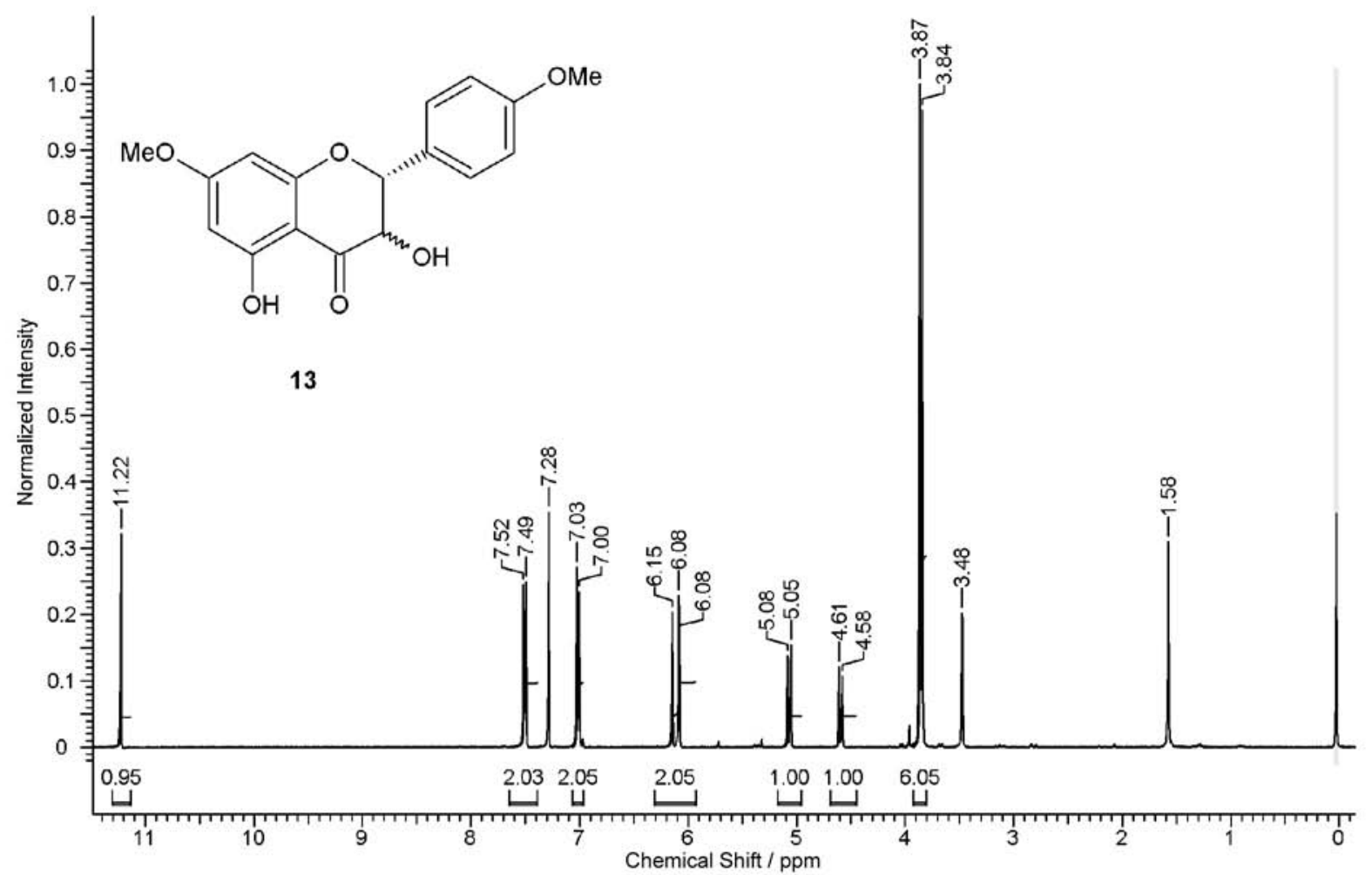

Figure S14. ${ }^{1} \mathrm{H}$ NMR spectrum of compound 13 , in $\mathrm{CDCl}_{3}$. 